\title{
Kasus Persalinan Dengan Bekas Seksio Sesarea Menurut Keadaan Waktu Masuk di Bagian Obstetri dan Ginekologi RSUP Dr. M. Djamil Padang
}

\author{
Anggy Afriani, Desmiwarti, Husnil Kadri
}

\begin{abstract}
Abstrak
Kehamilan dengan bekas seksio sesarea merupakan kehamilan dengan risiko tinggi sehingga persalinannya harus dilakukan di rumah sakit dengan fasilitas yang memadai. Ibu hamil dengan bekas seksio sesarea yang akan melakukan persalinan seharusnya datang ke rumah sakit dalam keadaan belum in partu, belum ada komplikasi persalinan. Namun, masih banyak ibu hamil dengan bekas seksio sesarea datang ke rumah sakit dalam keadaaan in partu. Penelitian ini bertujuan untuk mengetahui kasus-kasus persalinan dengan bekas seksio sesarea saat masuk ke bagian Obstetri dan Ginekologi RSUP.dr.M.Djamil Padang. Penelitian ini dilakukan pada ibu hamil dengan bekas seksio sesarea yang datang ke RSUP.dr.M.Djamil untuk melakukan persalinan. Penelitian dilakukan pada tanggal 22 Desember 2012-21 Maret 2013 di bagian Obstetri dan Ginekologi RSUP. dr. M. Djamil Padang. Penelitian ini merupakan studi deskriptif. Kasus-kasus persalinan dengan bekas seksio sesarea didapat dari observasi rekam medik dan mewawancarai subjek penelitian dengan menggunakan kuesioner. Hasil penelitian didapatkan 52 kasus persalinan dengan bekas seksio sesarea. Premature rupture of membrane (PRM) merupakan kasus persalinan dengan bekas seksio sesarea terbanyak yaitu 13 kasus (25\%) dan ibu hamil dengan bekas seksio sesarea yang melakukan rujukan dini berencana sebanyak 5,7\%. Simpulan dari penelitian adalah masih kurangnya kesadaran ibu hamil dengan bekas seksio sesarea yang akan melakukan persalinan untuk datang ke rumah sakit beberapa hari sebelum tanggal taksiran persalinan.
\end{abstract}

Kata kunci: bekas seksio sesarea, rujukan dini berencana

\begin{abstract}
Pregnancy with previous caesarean section is a high risk pregnancy. The delivery must be performed in hospital. The women who has previous caesarean section in their pregnancy must come to the hospital before the date of planned birth, no labor, and no complications for the woman and her infants. However, there are many woman with caesarean section come to the hospital in partu. The objective of this study to describe labor case of previous section birth when come to the Obstetric and Gynecology of dr.M.Djamil Padang Hospital. This study is descriptive .The subject of this study is a pregnant women with previous caesarean section who come to the dr.M.Djamil Padang hospital to the delivery. This study was performed from on 22rd December 2012 until 21 rdMarch 2013 in Obstetric and Gynecology of dr.M.Djamil Padang. The labor case of previous caesarean section are gotten from medical record and interview with use questionnaire. The result of this study is gotten fifty two labor cases of previous caesarean section. Premature rupture of membrane (PRM) is the mayority labor case, thirteen case (25\%) and account for 5,7\% of woman with previous caesarean section who early referral plan come to the hospital. The conclusion is the woman who have previous caesarean section are not awarness to come to the hospital a few days before the plan birth.
\end{abstract}

Keywords: previous caesarean section, early referral plan

Affiliasi penulis : Anggy Afriani,

Korespondensi : Fakultas Kedokteran Universitas Andalas, email : anggy.afriani@yahoo.com, Telp: 085263537241

\section{Pendahuluan}

Seksio sesarea merupakan suatu persalinan buatan, dimana janin dilahirkan melalui suatu insisi pada dinding rahim dengan syarat rahim dalam keadaan utuh dan berat janin lebih dari 500 gram. ${ }^{1}$ Dari tahun ke tahun angka kejadian seksio sesarea terus meningkat. Di Inggris, pada tahun 2008-tahun 2009 angka seksio sesarea menjadi $24,6 \%$ yang pada tahun 1980 hanya sekitar 9\%. Selain itu angka kejadian seksio sesarea di Australia pada tahun 1998 sekitar $21 \%$ dan pada tahun 2007 telah mencapai sekitar $31 \%{ }^{2}$ Di Indonesia angka kejadian seksio sesarea pada tahun 2009 telah mencapai $29,6 \%$. $^{3} \mathrm{Di}$ RSUP DR.M.Djamil Padang, kejadian seksio sesarea pada tahun 2000 sekitar $22,46 \%$, tahun 2001 sekitar $23,33 \%$, tahun 2002 sekitar $25,7 \%$, dan pada tahun 2003 sekitar $25,24 \%{ }^{4}$
Dengan meningkatnya frekuensi seksio sesarea ini, maka dapat meningkat pula angka kejadian ibu hamil dengan riwayat pernah melahirkan dengan seksio sesarea serta penyulit yang dialami saat persalinan. Di Inggris, frekuensi seksio sesarea ulangan pada ibu yang pernah seksio sesarea sebelumnya sekitar $28 \%$ dari kelahiran yang ada. Selain itu, di Australia selatan sekitar $56,6 \%$ seksio sesarea elektif dan $13,9 \%$ seksio sesarea emergensi dialami oleh ibu yang pernah seksio sesarea sebelumnya. $^{5}$ Di RSUP DR.M.Djamil Padang, kasus persalinan pada ibu dengan riwayat seksio sesarea pada persalinan sebelumnya pada tahun 2004 sekitar $8,90 \%{ }^{6}$

Kehamilan dan persalinan dengan riwayat seksio sesarea sebelumnya akan mendapat risiko terjadinya morbiditas dan mortalitas yang meningkat terutama berhubungan dengan parut uterus. ${ }^{7}$ Selain itu berdasarkan penelitian epidemiologik baik di rumah sakit rujukan (RSU dr.Sutomo) dan di luar rumah sakit didapatkan berbagai macam masalah kesehatan ibu 
hamil yang tercakup ke dalam dua puluh faktor risiko yang menggolongkan kehamilan dengan bekas seksio sesarea ke dalam kelompok faktor risiko I atau ibu dengan risiko tinggi sehingga persalinannya harus dilakukan di rumah sakit dengan fasilitas yang memadai dan ibu dengan kehamilan bekas seksio sesarea menjalani rujukan dini berencana. ${ }^{8}$ Setiap ibu hamil dengan bekas seksio sesarea haruslah melakukan pemeriksaan antenatal karena pada saat antenatal ibu hamil akan mendapat informasi tentang taksiran persalinan, persalinan dengan bekas seksio sesarea haruslah dilakukan di rumah sakit yang memiliki fasilitas kesehatan yang memadai, dan kapan waktu yang tepat untuk persalinan ke rumah sakit. ${ }^{7}$

RSUP dr. M. Djamil Padang merupakan rumah sakit rujukan yang menyelenggarakan pelayanan kesehatan kepada masyarakat. Di RSUP. dr.M.Djamil Padang, ibu hamil dengan bekas seksio sesarea dirawat dulu selama dua minggu sebelum taksiran persalinan untuk persiapan secara optimal sehingga persalinan dapat berjalan dengan lancar dan sesuai dengan yang direncanakan. ${ }^{9}$

Namun, menurut penelitian yang dilakukan oleh Sulaini (1991) berdasarkan data rekam medik dari tahun 1988- tahun 1990 didapatkan kasus persalinan bekas seksio sesarea yang masuk ke rumah sakit RSUP Dr. M. Djamil Padang pada saat persalinan telah dimulai yaitu tiga kasus observasi inpartu, 58 kasus kala I fase aktif, tigabelas kasus dengan PRM (Premature rupture of membrane), dua belas kasus kala I fase laten, dan tiga kasus dengan persalinan kala II.

Selain itu berdasarkan survei pendahuluan yang dilakukan oleh penulis dengan mengambil data laporan kasus persalinan di bagian Obstetri dan Ginekologi RSUP dr.M.Djamil Padang dari tanggal 12 Oktober 2011- tanggal 18 Januari 2012 didapatkan delapan kasus bekas seksio sesarea yang datang dengan keadaan parturien aterm kala I fase aktif, delapan kasus dengan keadaan parturien kala I fase laten, tujuh belas kasus datang dalam kehamilan aterm dengan kisaran 37 minggu-38 minggu, 38 minggu-39 minggu, 40 minggu- 41 minggu, dan 41 minggu-42 minggu, sisanya satu kasus kehamilan immatur 22 minggu-23 minggu dengan superimposed preeklamsia berat, satu kasus kehamilan postterm dengan oligohidramnion, dan satu kasus postpartus prematurus 35 minggu-36 minggu spontan anak pertama di luar dengan retensi janin kedua letak lintang kepala kiri dorsosuperior.

Penelitian yang dilakukan oleh Hidayat (1998) berdasarkan rekam medik RSUP.dr. Kariadi Semarang didapatkan 1,6 \% kematian bayi yang dilahirkan dari ibu hamil dengan bekas seksio sesarea yang mengalami ruptur uteri, tetapi tidak didapatkan kematian ibu. Ibu hamil dengan bekas seksio sesarea ini tidak melakukan rawat inap di rumah sakit sebelum taksiran persalinan atau datang dalam keadaan in partu. ${ }^{10}$

Penelitian ini betujuan untuk mengetahui kasus persalinan ibu bekas seksio sesarea saat masuk ke bagian Obstetri dan Ginekologi RSUP dr.M.Djamil Padang.

Metode

Penelitian dilakukan pada tanggal 22 Desember 2012-21 Maret 2013 di bagian kamar rawat Obstetri dan Ginekologi RSUP.dr.M.Djamil Padang. Populasi penelitian ini adalah ibu hamil dengan bekas seksio sesarea yang datang ke RSUP.dr.M.Djamil untuk melakukan persalinan. Sampel penelitian adalah semua populasi penelitian.Teknik pengambilan sampel yaitu consecutive sampling. Penelitian ini merupakan studi deskriptif. Data yang diambil berupa data primer (berupa data yang didapatkan dengan wawancara terarah menggunakan kuesioner untuk mengumpulkan informasi dari responden yaitu ibu pascapersalinan yang hamil dengan bekas seksio sesarea) dan data sekunder (berupa data yang didapatkan dari rekam medik responden di ruang kamar rawat kelas III bagian Obstetri dan Ginekologi RSUP dr.M.Djamil Padang. Data yang diperoleh diolah secara manual kemudian ditabulasikan, dianalisa dan disajikan dengan tabel.

\section{Hasil dan Pembahasan}

Jumlah kasus yang didapatkan selama penelitian ini adalah sebanyak 52 kasus.

\section{Karakteristik Subjek Penelitian \\ a. Umur}

Tabel 1 : Distribusi responden berdasarkan umur

\begin{tabular}{lcc}
\hline \multirow{2}{*}{ UMUR } & \multicolumn{2}{c}{$\begin{array}{c}\text { lbu hamil dengan } \\
\text { bekas seksio sesarea }\end{array}$} \\
\cline { 2 - 3 } & \multicolumn{2}{c}{$\mathrm{f}$} \\
& & \\
\hline 20-24 tahun & 6 & 11,5 \\
25-29 tahun & 12 & 23,1 \\
30-34 tahun & 19 & 36,5 \\
35-39 tahun & 11 & 21,1 \\
40-44 tahun & 4 & 7,7 \\
Jumlah & 52 & 99,9 \\
\hline
\end{tabular}

Tabel 2: Rata-rata umur responden

\begin{tabular}{lll}
\hline Umur Termuda & Umur Tertua & Rata-rata \\
\hline 20 tahun & 43 tahun & 31,44 tahun \\
\hline
\end{tabular}

Berdasarkan tabel diatas didapatkan bahwa golongan umur 30 tahun -34 tahun merupakan rentang umur tertinggi ibu hamil dengan bekas seksio sesarea yang datang ke RSUP dr.M.Djamil Padang untuk melakukan persalinan yaitu sebesar $36,5 \%$. Didapatkan umur termuda yaitu umur 20 tahun dan umur tertinggi yaitu umur 43 tahun. Hal ini tidak jauh berbeda dengan penelitian yang dilakukan oleh Sulaini (1991) di bagian Obstetri dan Ginekologi RSUP dr.M.Djamil Padang menemukan frekuensi tertinggi persalinan dengan bekas seksio sesarea pada golongan umur 25 tahun - 29 tahun yaitu 42,57\%. Ini berarti usia ibu hamil dengan bekas seksio sesarea masih berada dalam kategori usia reproduksi. 
b. Paritas

Tabel 3 : Distribusi paritas sebelumnya ibu hamil dengan bekas seksio sesarea

\begin{tabular}{lllllll}
\hline Paritas & \multicolumn{2}{l}{ SC 1X } & \multicolumn{2}{l}{ SC 2x } & \multicolumn{2}{l}{ SC 3 x } \\
\cline { 2 - 7 } & $f$ & $\%$ & $f$ & $\%$ & $f$ & $\%$ \\
\hline 2 & 35 & 67,3 & 0 & 0 & 0 & 0 \\
3 & 4 & 7,7 & 7 & 13,5 & 0 & 0 \\
4 & 2 & 3,8 & 2 & 3,8 & 0 & 0 \\
5 & 0 & 0 & 0 & 0 & 1 & 1,9 \\
6 & 1 & 1,9 & 0 & 0 & 0 & 0 \\
\hline
\end{tabular}

Berdasarkan tabel di atas didapatkan paritas 2 dengan bedah seksio sesarea sebelumnya satu kali yaitu sebesar $67,3 \%$. Paritas tertinggi yaitu paritas 6 dengan bedah seksio sesarea satu kali yaitu sebesar 1,9\%.Demikian pula penelitian yang dilakukan oleh Hidayat (1998) mendapatkan paritas 2 merupakan paritas terbanyak pada ibu hamil dengan bekas seksio sesarea yaitu sebesar $65,8 \%$, yang paritas pertamanya dilakukan dengan cara bedah seksio sesarea.

\section{c. Tingkat Pendidikan}

Tabel 4 : Distribusi tingkat pendidikan

\begin{tabular}{lll}
\hline Tingkat pendidikan & $\mathrm{f}$ & $\%$ \\
\hline Tidak tamat sekolah/SD & 1 & 1,9 \\
SD/tidak tamat SMP & 10 & 19,2 \\
SMP/tidak tamat SMA & 5 & 9,6 \\
SMA/tidak tamat PT & 33 & 63,5 \\
PT & 3 & 5,8 \\
\hline
\end{tabular}

Berdasarkan tabel di atas didapatkan distribusi tingkat pendidikan ibu hamil dengan bekas seksio sesarea pada penelitian ini yang terbanyak adalah SMA/tidak tamat PT (63,5\%). Demikian juga yang didapatkan oleh Hidayat (1998) dan Agustina (2008). Hidayat mendapatkan lama pendidikan ibu hamil dengan bekas SC yang terbanyak yaitu 10-12 tahun (43,7\%), setingkat SMA, dan Agustina juga mendapatkan tingkat SMA merupakan tingkat pendidikan terbanyak yaitu 25 orang. Sekolah menengah atas merupakan lanjutan dari jenjang pendidikan dasar. Ini berarti ibu hamil dengan bekas seksio sesarea ini mudah menerima dan memahami informasi yang disampaikan oleh bidan atau dokter saat mereka melakukan kunjungan antenatal.

\section{d. Tingkat penghasilan}

Tabel 5 : Distribusi tingkat penghasilan

\begin{tabular}{lll}
\hline Tingkat Penghasilan & $f$ & $\%$ \\
\hline <Rp1.150.000,00 & 20 & 38,5 \\
Rp1.150.000,00 & 14 & 26,9 \\
>Rp1.150.000,00 & 17 & 34,6 \\
\hline
\end{tabular}

Berdasarkan tabel di atas didapatkan distribusi tingkat penghasilan keluarga yang paling banyak pada penelitian ini yaitu penghasilan kurang dari Rp1.150.000,00 (38,5\%). Penghasilan kurang dari Rp1.150.000,00 ini masih berada di bawah batas upah minimum regional yang ditetapkan oleh Gubernur propinsi Sumatera Barat tahun 2012

\section{e. Ibu Hamil dengan Bekas Seksio Sesarea yang Ingat dengan Hari Pertama Haid Terakhir (HPHT)nya.}

Tabel 6 : Distribusi ibu hamil dengan bekas seksio sesarea yang ingat dengan HPHTnya

\begin{tabular}{lcc}
\hline HPHT & $\mathrm{f}$ & $\%$ \\
\hline Ingat & 46 & 88,5 \\
Tidak ingat & 6 & 11,5 \\
Jumlah & 52 & 100 \\
\hline
\end{tabular}

Berdasarkan tabel di atas didapatkan ibu hamil dengan bekas seksio sesarea yang ingat dengan hari pertama haid terakhirnya yaitu sebesar $88,5 \%$. Ini berarti pendidikan tentang kesehatan reproduksi khususnya mengenai pentingnya pencatatan hari pertama haid terakhir mereka berjalan dengan baik. Selain itu, dengan mengetahui hari pertama haid terakhir akan memudahkan penentuan usia kehamilan dan informasi taksiran persalinan.

2. Usia Kehamilan Saat Masuk ke RSUP . DR. M. Djamil Padang

Tabel 7: Distribusi usia kehamilan saat masuk ke RSUP dr.M.Djamil Padang

\begin{tabular}{lll}
\hline Usia Kehamilan & $\mathbf{f}$ & $\%$ \\
& & \\
\hline$<38$ minggu (preterm) & 9 & 17,3 \\
38 minggu-42 minggu (aterm) & 43 & 82,7 \\
$>42$ minggu (postterm) & 0 & 0 \\
\hline
\end{tabular}

Berdasarkan tabel di atas didapatkan bahwa ibu bekas seksio sesarea yang datang ke RSUP dr.M.Djamil Padang untuk persalinan kebanyakan datang dengan usia kehamilan aterm yaitu sebesar $82,7 \%$.

3. Diagnosa Saat Masuk ke Bagian Obstetri dan Ginekologi RSUP DR.M. Djamil Padang

Tabel 8 : Distribusi diagnosa saat masuk ke bagian Obstetri dan Ginekologi RSUP dr. M. Djamil Padang

\begin{tabular}{llrr}
\hline No & \multicolumn{2}{c}{ Diagnosa saat masuk } & \multicolumn{2}{c}{ Jumlah } \\
\cline { 3 - 4 } & & $\mathrm{f}$ & $\%$ \\
\hline 1 & Gravid aterm & 6 & 11,5 \\
2 & Gravid aterm+premature ruptur of & 13 & 25 \\
& membran(PRM) & & \\
3 & Gravid aterm+oligohidramnion & 1 & 1,9 \\
4 & Gravid aterm+hemoragic antepartum & 2 & 3,8 \\
& ec.plasenta previa totalis & & \\
5 & Gravid aterm+letak sungsang & 1 & 1,9 \\
6 & Gravid aterm+letak sungsang+PRM & 2 & 3,8 \\
7 & Gravid aterm+kontraksi & 3 & 5,8 \\
8 & Gravid preterm & 1 & 1,9 \\
9 & Gravid preterm+PRM & 3 & 5,8 \\
10 & Gravid preterm+partus prematurus & 3 & 5,8 \\
& iminens & & \\
11 & Gravid preterm+preeklamsia berat(PEB) & 1 & 1,9 \\
12 & Gravid preterm+PEB+HELLP syndrome & 1 & 1,9 \\
13 & Parturien aterm kala I fase aktif & 4 & 7,7 \\
14 & Parturien aterm kala I fase laten & 10 & 19,2 \\
15 & Postpartus prematurus spontan+PEB & 1 & 1,9 \\
\hline
\end{tabular}


Berdasarkan tabel di atas dapat dilihat bahwa diagnosa ibu hamil dengan bekas seksio sesarea saat masuk ke bagian Obstetri dan Ginekologi yang paling banyak terjadi adalah gravid aterm dengan premature rupture of membrane (PRM) sebanyak 13 kasus (25\%) dan parturien aterm kala I fase laten sebanyak 10 kasus (19,2\%).

Pada penelitian ini didapatkan bahwa dari 52 kasus persalinan dengan bekas seksio sesarea yang diteliti didapatkan kasus gravidarum aterm dengan premature rupture of membrane (PRM) yang paling banyak terjadi yaitu sebanyak 13 kasus (25\%). Premature rupture of membrane merupakan keadaaan pecahnya selaput ketuban sebelum persalinan. Komplikasi yang terjadi akibat adanya premature rupture of membrane adalah infeksi maternal maupun neonatal, hipoksia karena kompresi tali pusat, deformitas janin, meningkatnya insiden seksio sesarea persalinan prematur, atau gagalnya persalinan normal. Risiko terjadinya infeksi postpartum pada ibu dan infeksi neonatus meningkat pada kejadian premature rupture of membrane. ${ }^{11}$

Hal ini berbeda dengan penelitian yang dilakukan Sulaini (1991). Sulaini mendapatkan bahwa kala I fase aktif merupakan kasus persalinan dengan bekas seksio sesarea yang paling banyak terjadi yaitu sebanyak 58 kasus $(65,16 \%)$, dan kasus kedua terbanyak yaitu premature rupture of membrane sebanyak 13 kasus (14,61\%). Menurut penelitian yang dilakukan oleh Hidayat (1998), ibu hamil dengan bekas seksio sesarea yang datang ke RSUP dr.Kariadi untuk persalinan, didapatkan 58 kasus $(49,21 \%)$ datang ke RSUP dr.Kariadi dalam keadaaan belum in partu, 57 kasus $(48,3 \%)$ datang dalam keadaaan in partu kala I, dan tiga pasien dalam keadaan in partu kala II. Selain itu, didapatkan dua pasien $(1,7 \%)$ mengalami ruptur uteri dan dua orang mengalami dehisens. Kedua pasien yang mengalami ruptur uteri datang dalam keadaan in partu kala I, salah satu dari pasien ini ada riwayat ditolong oleh dukun sebelum dirujuk ke RS.dr.Kariadi.

4. Jumlah kunjungan dan tempat antenatal kehamilan sekarang ibu hamil dengan bekas seksio sesarea

Tabel 9 : Distribusi jumlah kunjungan dan tempat antenatal care (ANC) kehamilan sekarang ibu hamil dengan bekas seksio sesarea

\begin{tabular}{|c|c|c|c|c|c|c|}
\hline \multirow{3}{*}{$\begin{array}{l}\text { Tempat } \\
\text { ANC }\end{array}$} & \multicolumn{4}{|c|}{ Jumlah } & \multicolumn{2}{|c|}{ Jumlah } \\
\hline & \multicolumn{2}{|c|}{$<4$ kali } & \multicolumn{2}{|c|}{$>4$ kali } & & \\
\hline & $f$ & $\%$ & $f$ & $\%$ & $f$ & $\%$ \\
\hline Bidan & 2 & 3,8 & 24 & 46,1 & 26 & 49,9 \\
\hline Dokter & 0 & 0 & 3 & 5,8 & 3 & 5,8 \\
\hline Bidan+dokter & 0 & 0 & 16 & 30,8 & 16 & 30,8 \\
\hline $\begin{array}{l}\text { Bidan+dokter } \\
\text { spesialis Kebidanan }\end{array}$ & 0 & 0 & 3 & 5,8 & 3 & 5,8 \\
\hline $\begin{array}{l}\text { Bidan+dokter+dokter } \\
\text { spesialis Kebidanan }\end{array}$ & 0 & 0 & 3 & 5,8 & 3 & 5,8 \\
\hline Jumlah & 2 & 3,8 & 49 & 94,3 & 51 & 98,1 \\
\hline
\end{tabular}

Tabel 10 : Distribusi ibu bekas seksio sesarea yang ANC ke bidan yang dirujuk oleh bidan ke RSUP dr.M.Djamil Padang $(\mathrm{f}=11)$

\begin{tabular}{lll}
\hline Rujukan oleh bidan & $\mathrm{f}$ & $\%$ \\
\hline Keadaan in partu & 9 & 81,8 \\
Keadaan tidak in partu & 2 & 18,2 \\
\hline
\end{tabular}

Berdasarkan tabel 9 di atas dapat dilihat bahwa tempat pemeriksaan antenatal yang paling banyak dikunjungi adalah di bidan sebesar 49,9\% dengan jumlah kunjungan lebih dari empat kali sebesar 94,3\%. Selain itu, didapatkan juga satu responden yang tidak melakukan pemeriksaan antenatal selama kehamilan yang sekarang. Berdasarkan tabel 10 didapatkan bahwa dari 26 orang ibu hamil dengan bekas seksio sesarea yang melakukan pemeriksaan antenatal ke tempat bidan hanya sebelas orang yang dirujuk oleh bidan, sembilan orang $(81,8 \%)$ dirujuk dalam keadaan in partu dan dua orang $(18,2 \%)$ dirujuk dalam keadaan tidak in partu (saat pemeriksaan antenatal).

Pada penelitian ini didapatkan bahwa tempat pemeriksaan antenatal yang paling banyak dikunjungi adalah di bidan sebesar 49,9\% dengan jumlah kunjungan lebih dari empat kali sebesar $94,3 \%$. Bidan merupakan tenaga profesional yang bekerja sebagai mitra perempuan untuk memberikan dukungan, asuhan, dan nasehat selama masa hamil, masa persalinan, dan masa nifas. Asuhan ini mencakup upaya pencegahan, promosi persalinan normal, deteksi komplikasi pada ibu dan anak, dan akses bantuan medis atau bantuan lain yang sesuai. Beberapa dari tugas bidan adalah memberikan asuhan kebidanan melalui konsultasi dan rujukan pada ibu hamil dengan risiko tinggi dan kegawatdaruratan dan memberikan asuhan kebidanan melalui konsultasi dan rujukan pada masa persalinan dengan penyulit tertentu. ${ }^{1}$

Penelitian yang dilakukan oleh Sulaini (1991) didapatkan tempat pemeriksaan antenatal terbanyak adalah puskesmas yaitu 30 kasus $(33,71 \%)$ dengan jumlah kunjungan pemeriksaan antenatal sebanyak lebih dari empat kali yaitu 80 kasus (86,89\%). Menurut Hidayat (1998) yang melakukan penelitian terhadap ibu hamil dengan bekas seksio sesarea di RSUP dr.Kariadi Semarang yaitu semua pasien melakukan pemeriksaan antenatal, 40 pasien $(33,84 \%)$ melakukan di bidan praktik, 38 pasien $(30,83 \%)$ di rumah sakit, dan sisanya di puskesmas $(21 \%)$, dokter umum $(1 \%)$ dan di dokter spesialis (13\%).

\section{Asal Rujukan lbu Hamil dengan Bekas Seksio Sesarea ke bagian Obstetri dan Ginekologi RSUP.DR.M. Djamil Padang}

Tabel 11 : Distribusi asal rujukan ibu hamil dengan bekas seksio sesarea yang melakukan persalinan di RSUP dr.M.Djamil Padang $(\mathfrak{f}=52)$

\begin{tabular}{|c|c|c|c|c|c|c|}
\hline \multirow[t]{2}{*}{$\begin{array}{l}\text { Asal Rujukan ke Bagian } \\
\text { Obstetri }\end{array}$} & \multicolumn{2}{|c|}{ Dirujuk } & \multicolumn{2}{|c|}{$\begin{array}{l}\text { Datang } \\
\text { Sendiri }\end{array}$} & \multicolumn{2}{|c|}{ Total } \\
\hline & $f$ & $\%$ & $f$ & $\%$ & $f$ & $\%$ \\
\hline $\begin{array}{l}\text { Poli Kebidanan RSUP } \\
\text { dr.M.Djamil Padang }\end{array}$ & 2 & 3,8 & 1 & 1,9 & 3 & 5,7 \\
\hline $\begin{array}{l}\text { IGD RSUP dr. M. Djamil } \\
\text { Padang }\end{array}$ & 30 & 57,7 & 1 & $\begin{array}{l}36, \\
5\end{array}$ & $\begin{array}{l}4 \\
9\end{array}$ & 94,2 \\
\hline Total & 32 & 61,5 & $\begin{array}{l}2 \\
0\end{array}$ & $\begin{array}{l}38, \\
4\end{array}$ & $\begin{array}{l}5 \\
2\end{array}$ & 99,9 \\
\hline
\end{tabular}


Tabel 12 : Distribusi diagnosis ibu hamil dengan bekas seksio sesarea yang datang ke IGD RSUP dr.M.Djamil Padang melalui rujukan $(\mathrm{f}=30)$

\begin{tabular}{|c|c|c|}
\hline Diagnosis saat masuk & $f$ & $\%$ \\
\hline Gravid aterm & 2 & 6,7 \\
\hline Gravid aterm+letak sungsang & 1 & 3,3 \\
\hline $\begin{array}{l}\text { Gravid aterm+hemorrhagic antepartum } \\
\text { e.c Plasenta previa totalis }\end{array}$ & 2 & 6,7 \\
\hline $\begin{array}{l}\text { Gravid aterm+premature rupture of } \\
\text { membrane }\end{array}$ & 7 & 23,3 \\
\hline Gravid aterm + kontraksi & 1 & 3,3 \\
\hline Gravid aterm + letak sungsang & 2 & 6,7 \\
\hline Gravid preterm & 1 & 3,3 \\
\hline $\begin{array}{l}\text { Gravid preterm+partus prematurus } \\
\text { iminens }\end{array}$ & 2 & 6,7 \\
\hline Gravid preterm+preeklamsia antepartum & 1 & 3,3 \\
\hline Gravid preterm+PEB+HELLP Syndrone & 1 & 3,3 \\
\hline kala I fase laten & 6 & 20 \\
\hline aktif & 3 & 10 \\
\hline Post partus spontan+preeklamsia bera & 1 & 3,3 \\
\hline
\end{tabular}

Tabel 13 : Distribusi diagnosis ibu hamil dengan bekas seksio sesarea yang datang sendiri (tanpa rujukan) ke IGD RSUP dr.M.Djamil Padang $(\mathrm{f}=30)$

\begin{tabular}{lll}
\hline Diagnosis saat masuk & $\mathrm{f}$ & $\%$ \\
\hline Gravid aterm & 3 & 10 \\
Gravid aterm+kontraksi & 1 & 3,3 \\
Gravid aterm+IUGR+oligohidramnion & 1 & 3,3 \\
Gravid aterm+premature rupture of & 7 & 23,3 \\
membrane & & \\
Gravid aterm+kontraksi & 1 & 3,3 \\
Gravid preterm+PRM & 3 & 10 \\
Parturien aterm kala I fase laten & 3 & 10 \\
Parturien aterm kala I fase aktif & 1 & 3,3 \\
\hline
\end{tabular}

Berdasarkan tabel 11 dapat dilihat bahwa ibu hamil dengan bekas seksio sesarea yang datang dengan rujukan dini berencana (melalui Poli Kebidanan RSUP dr.M.Djamil Padang) ke bagian Obstetri RSUP dr.M.Djamil Padang yaitu sebesar $5,7 \%$ dan rujukan yang paling banyak terjadi yaitu rujukan melalui IGD (Instalasi Gawat Darurat) RSUP dr. M. Djamil Padang sebanyak $57,7 \%$ dan kasus gravidarum aterm dengan premature rupture of membran merupakan kasus terbanyak yaitu $23,3 \%$. Selain itu, ibu hamil dengan bekas seksio sesarea yang datang sendiri (tanpa rujukan) ke IGD RSUP dr.M.Djamil Padang sebanyak 19 orang (36,5\%) dan kasus gravidarum aterm dengan premature rupture of membrane juga merupakan kasus terbanyak yaitu sebesar $23,3 \%$.

Pada penelitian ini dapat dilihat bahwa ibu hamil dengan bekas seksio sesarea yang datang dengan rujukan dini berencana yaitu sebesar $5,7 \%$. Satu orang dari mereka melakukan pemeriksaan antenatal di praktik bidan, kemudian pada kehamilan trimester III dengan kesadaran sendiri melakukan pemeriksaan antenatal ke poli Kebidanan RSUP dr.M.Djamil Padang. Dua orang lainnya melakukan kunjungan ke poli Kebidanan RSUP dr.M.Djamil Padang setelah dirujuk oleh bidan. Kisaran persentase ibu hamil dengan bekas seksio yang melakukan rujukan dini berencana ke rumah sakit pada penelitian ini sekitar $5,7 \%$, sedangkan kehamilan dengan bekas seksio sesarea merupakan kehamilan dengan risiko tinggi yang persalinannya harus dilakukan di rumah sakit. Seharusnya selama antenatal bidan mengadvokasi ibu hamil dengan bekas seksio sesarea untuk melakukan rujukan dini berencana. Bidan memiliki tugas memberikan asuhan kebidanan melalui konsultasi dan rujukan pada ibu hamil dengan risiko tinggi dan kegawatdaruratan, dan memberikan asuhan kebidanan melalui konsultasi dan rujukan pada masa persalinan dengan penyulit tertentu. ${ }^{12}$

Rujukan yang paling banyak terjadi yaitu rujukan oleh tenaga kesehatan (bidan dan dokter) melalui IGD (Instalasi Gawat Darurat) RSUP dr.M.Djamil Padang sebanyak 57,7\%, dengan diagnosis saat masuk terbanyak yaitu gravidarum aterm dengan premature rupture of membrane $(23,3 \%)$. Hal ini dikarenakan mereka umumnya melakukan pemeriksaan antenatal di praktik bidan kemudian baru dirujuk ke rumah sakit. Selain itu, didapatkan 19 orang $(36,5 \%)$ ibu hamil dengan bekas seksio sesarea yang datang sendiri ke IGD RSUP dr.M.Djamil Padang dengan diagnosis saat masuk terbanyak yaitu gravidarum aterm dengan premature rupture of membrane sebesar $23,3 \%$. Hal ini tidak sesuai dengan program pemerintah dalam program rujukan untuk menurunkan angka kematian ibu yaitu ibu dengan kehamilan atau persalinan dengan bekas seksio sesarea merupakan ibu risiko tinggi dan termasuk ke dalam kelompok faktor risiko I AdaPotensi-Gawat-Obstetrik (APGO) dan harus melakukan rujukan dini berencana. ${ }^{8}$

Berdasarkan hasil penelitian Hidayat (1998) didapatkan 44 kasus $(28,2 \%)$ rujukan ibu hamil dengan bekas seksio sesarea oleh bidan dan empat pasien yang tidak pernah rawat inap, datang sendiri ke RSUP dr.Kariadi, tanpa surat rujukan. Namun, menurut penelitian yang dilakukan oleh Agustina terhadap ibu hamil dengan bekas seksio sesarea yang akan menjalani persalinan pervaginam pasca bedah seksio sesarea di bagian Obstetri RSUP dr.Kariadi Semarang didapatkan $53,15 \%$ ibu hamil dengan bekas seksio sesarea datang dengan rujukan dini berencana, dan 16,3\% dirujuk langsung oleh bidan. Hal ini terjadi karena bidan sudah mengetahui mengenai persalinan pervaginam pasca bedah seksio sesarea merupakan persalinan dengan risiko tinggi. ${ }^{13}$

\section{Informasi tentang Rencana Persalinan pada} Kehamilan dengan Bekas Seksio Sesarea

Tabel 14 : Distribusi informasi tentang taksiran persalinan

\begin{tabular}{lcc}
\hline $\begin{array}{l}\text { Informasi taksiran } \\
\text { persalinan }\end{array}$ & $\mathrm{f}$ & $\%$ \\
\hline Ada & 46 & 88,5 \\
Tidak ada & 6 & 11,5 \\
\hline
\end{tabular}

Tabel 15 : Distribusi informasi tentang rumah sakit rujukan sebagai tempat persalinan dengan bekas seksio sesarea

\begin{tabular}{lcc}
\hline Info rumah sakit rujukan & $\mathrm{f}$ & $\%$ \\
\hline Ada & 46 & 88,5 \\
Tidak ada & 6 & 11,5 \\
\hline
\end{tabular}

Pada penelitian ini dapat dilihat bahwa ibu hamil dengan bekas seksio sesarea yang mengetahui informasi tentang taksiran persalinannya yaitu sebesar 46 orang $(88,5 \%)$ dan yang tidak mengetahui tentang taksiran persalinannya sebanyak enam orang $(11,5 \%)$. $\mathrm{Hal}$ ini karena mereka lupa hari pertama haid terakhirnya. Taksiran persalinan bisa dijadikan tolak ukur waktu bagi ibu hamil dengan bekas seksio sesarea harus pergi ke rumah sakit rujukan untuk melakukan persalinan sehingga ibu hamil dengan bekas seksio sesarea datang ke rumah sakit masih 
sehat belum in partu, belum ada komplikasi persalinan. Namun, jika dilihat dari hasil penelitian masih banyak ibu hamil dengan bekas seksio sesarea datang ke RSUP dr. M. Djamil Padang dalam keadaan premature rupture of membrane (PRM), kala I fase laten, dan kasus-kasus lainnya.

Pada penelitian ini dapat juga dilihat bahwa ibu hamil dengan bekas seksio sesarea yang mengetahui informasi mengenai rumah sakit rujukan sebagai tempat persalinannya yaitu sebesar 46 orang $(88,5 \%)$. Ibu hamil dengan bekas seksio sesarea merupakan kehamilan dengan risiko tinggi dan persalinan harus dilakukan di rumah sakit dengan peralatan yang memadai sehingga dapat meminimalisir kemungkinan komplikasi persalinan yang berakibat fatal.

\section{Kesimpulan}

Berdasarkan penelitian yang telah dilakukan, dapat disimpulkan bahwa :

1. Karakteristik ibu hamil dengan bekas seksio sesarea yang datang untuk persalinan ke bagian Obstetri dan Ginekologi RSUP dr. M. Djamil Padang yaitu paling banyak datang dengan rentang umur 30 tahun -34 tahun, paritas dua dengan bedah seksio sesarea sebelumnya satu kali, riwayat pendidikan terakhir adalah sekolah menengah atas, tingkat penghasilan keluarga masih dibawah upah minimum regional propinsi Sumatera Barat tahun 2012, dan banyak yang ingat dengan hari pertama haid terakhirnya.

2. Ibu hamil dengan bekas seksio sesarea rajin melakukan pemeriksaan antenatal dan tempat pemeriksaan antenatal yang paling sering dikunjungi adalah bidan.

3. Asal rujukan yang paling banyak terjadi yaitu rujukan oleh tenaga kesehatan (bidan dan dokter) melalui IGD (Instalasi Gawat Darurat) RSUP dr.M.Djamil Padang dengan diagnosis saat masuk terbanyak yaitu gravidarum aterm dengan premature rupture of membrane.

\section{Daftar Pustaka}

1. Angsar, MD dan Lilakusuma LS. IImu bedah kebidanan Sarwono Prawirohardjo, cetakan ke-7. Jakarta: Yayasan Bina Pustaka Sarwono Prawirohardjo; 2007.

2. Kealy, MA, Small RE, Lamputtong P.Recovery after caesarean birth : a qualitative study of women's accounts in Victoria, Australia. BMC Pregnancy and Childbirth.2010; 10: 47.

3. Festin MR, Laopaiboon M, Pattanittum P, Ewens MR, Henderson-Smart DJ,KealyCAC. Caesarean section in four south east asian countries: reason for rates, associated care practices, and health outcomes. BMC Pregnancy and Chilbirth.2009;9: 17.

4. Kurniawan, E. Gambaran kasus persalinan seksio sesarea di bagian Obstetrik dan Ginekologi Perjan RS. dr. M. Djamil Padang tahun 2003.(Skripsi).Universitas Andalas Padang. 2005.

5. Dodd M, Crowther CA, Hiller JE, Haslam RR, Robinson JC. Birth after caesarean study-planned vaginal birth or planned elective repeat caesarean birth : protocol for a patient preference study and randomised trial. BMC Pregnancy and Childbirth.2007; 7: 17.

6. Hamdani, R. Gambaran persalinan pervaginam pada pasien bekas SC di RS.dr.M.Djamil Padang tahun 2004.(Skripsi).Universitas Andalas Padang.2005.

7. Wirakusumah, FF. Kehamilan dan persalinan dengan parut uterus. Dalam IImu Kebidanan Sarwono Prawirohardjo edisi 4. Jakarta: PT Bina Pustaka Sarwono Prawirohardjo;2008.hlm. 615-16

8. Rochjati, P. Pelayanan kebidanan di Indonesia. Dalam Ilmu Kebidanan Sarwono Prawirohardjo edisi 4. Jakarta: PT Bina Pustaka Sarwono Prawirohardjo;2008.hlm. 29-32

9. Sulaini, P. Tinjauan persalinan bekas seksio sesarea di RSUP DR.M.Djamil Padang 19881990.(Tesis). Universitas Andalas Padang.1991.

10. Hidayat, Syarief Thaufiq.Persalinan pasien pasca bedah caesar.(Tesis).Universitas Diponegoro, Semarang.1998.

11. Soewarto, Soetomo. Ketuban pecah dini. Dalam Ilmu Kebidanan Sarwono Prawirohardjo edisi 4. Jakarta: PT Bina Pustaka Sarwono Prawirohardjo;2008.hlm. 677-79

12.Diah. Peran dan Fungsi Bidan. Diakses tanggal 8 Mei 2013 jam 13.59 WIB,2012. http://jurnalbidandiah.blogspot.com/2012/06/perandan-fungsi-bidan-dalam-pelayanan.html.

13. Agustina, Winda. Luaran maternal dan perinatal pada persalinan pervaginam pasca bedah sesar di RSUP.DR.Kariadi Semarang tahun 20072011.(Karya Tulis IImiah).Universitas Diponegoro Semarang.2012. 